\title{
PHYTOSYNTHESIS OF SILVERNANO PARTICLES AND ITS APPLICATIONS A CRITICAL STUDY
}

\author{
Minakshi Gajanan Pawar \\ School of Life Sciences \\ SRTMU Nanded, Maharashtra, India
}

\author{
Ramjan M. Mulani \\ Director, School of Life Sciences \\ SRTMU Nanded, Maharashtra, India
}

\begin{abstract}
Plants are enormous, easily available natural sources of biomolecules for the synthesis of nanoparticles. Until now about 2000 plants are used for the green synthesis of Nanoparticles. The secondary metabolites present in the plant are a source of capping and stabilizing agents more than $\mathbf{1 0 0}$ different biological sources for synthesizing Silver Nanoparticles are reported till date. It is found out by various reports that the reaction condition and the physiological condition of plant extract are the major factors for the synthesis of Silver Nanoparticles. The other physical factors which affect the size, shape, of Silver Nanoparticles include temperature, stirring the reaction mixture, the concentration of plant extract, and $p h$ of the plant extract. In this review article various aspects of Nanobiotechnology, the reaction of Nanoparticles synthesis, applications of Silver Nanoparticles are summarized and it is critically reviewed.
\end{abstract}

Keywords: Antimicrobial agent Nanobiotechnology, Nanoparticles, plant-mediated synthesis of Silver

\section{INTRODUCTION}

Nanotechnology is an interdisciplinary field integrated with diverse disciplines of chemistry, biology, material science, and engineering. More profoundly it can be defined as a science of the nanoscale object while Nanoparticles are defined as ultra-fine substances of the 10-9 the prefix nano is derived from the Greek word Nano meaning Dwarf. Today it is used as a prefix describing 10-9. The Nano materials are having the Diameter within the range of $100 \mathrm{~nm}$ with at least one dimension. The first time the term nanotechnology was introduced by Norio Taniguchi. The concept of nanotechnology was introduced by physicist Richard Feynman who urged the possibility of synthesis via direct manipulation of atom in his popular take ' threes plenty of room at the bottom. The concept of Richard freeman. Was come into the limelight in the 1980s after the discovery of the scanning tunnelling microscope and the discovery of fullerene[1,2].

In ancient period colloidal suspension of silver and gold were used as colorant, Lycurgus cup of fourth century $\mathrm{AD}$, contain colloidal silver and gold. In $17^{\text {th }}$ century, Severna Beams used by Indian people in
Ayurvedic medicine for the treatment of rheumatoid arthritis, which contains powdered gold NPs. First rationalized report on synthesis of gold NPs was in 1857 when Faraday chemically synthesizes gold NPs [3].Two approaches were used by the researcher for the fabrication of NSP ."Top- down"and"bottom-up" . In top down method, bulk materials are broken into nano sizes while in bottom up approach nuclei are self-assembled to generate nano size products.

There are various method includes chemical reduction, gamma ray radiation, microwave assistant vapour deposition, thermal reduction $[4,5,6]$

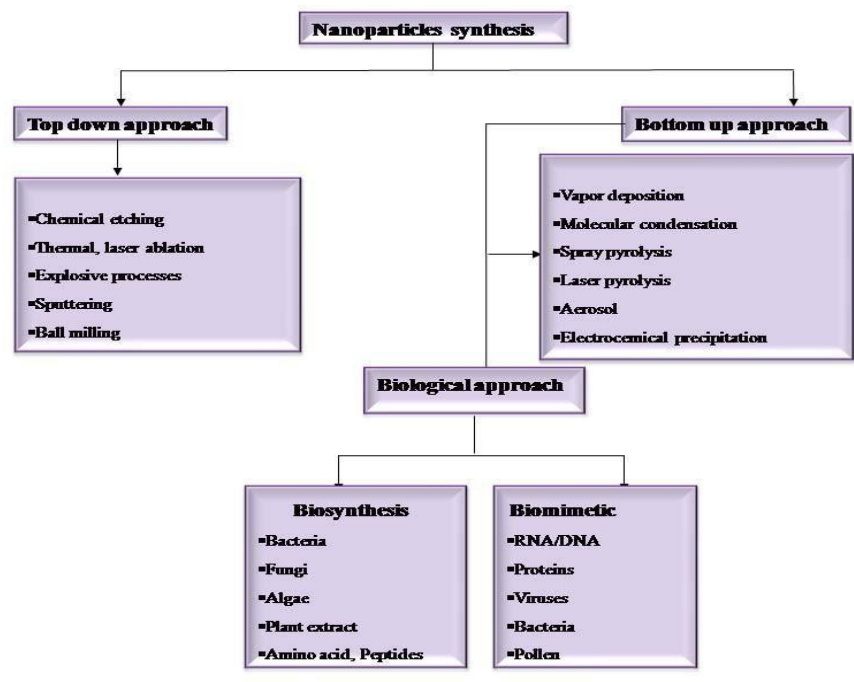

Fig No.1: Methods Nanoparticle Synthesis

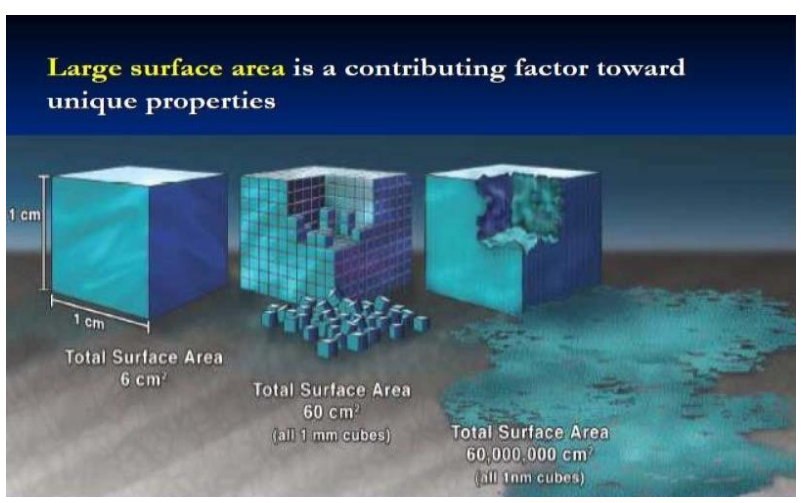

Fig No.2: Illustration of surface area of NPs 


\section{International Journal of Engineering Applied Sciences and Technology, 2021 \\ Vol. 5, Issue 9, ISSN No. 2455-2143, Pages 189-194 \\ Published Online January 2021 in IJEAST (http://www.ijeast.com)}

Wide range of methods including physical, chemical and biological methods have been used for the fabrication of NPs. Physical and chemical methods are popular because they have generated large number of NPs within short time[7-8]

Recently nature`s most elegant creators living organism and their parts are used for the synthesis of NPs. In biological systems, various nanosized materials are being found like DNA, RNA, rustry proteins, corals, bones, enamel etc. The NPs syntheses by living organisms are of two types; biologically controlled and biologically induced. Biologically controlled synthesis is natural ability of living system to synthesized NPs, which is also known as bio minerlization. While in biologically induced method organisms are forced to synthesize NPs $[9,10,11]$.Tolerance to the high concentration of toxic metal ion and their detoxification by microorganisms attracted an attention of scientific community to explore them for the synthesis of inorganicNPs. Since two decade, microorganisms are being used for the synthesis of various NPs. While in bio mimetic approach, NPs were synthesized by using biological structures as template.

\section{OPTICAL PROPERTIES}

Various metal and semiconductor NPs, when exposed to electromagnetic radiation (visible to near infrared region), shows colour variation, which occurs from alteration of their sizes, shapes, compositions etc When conducting band electron interact with electromagnetic radiation, dipole oscillations across the particle sphere takes place. Thus electron density of surface layer changes which leads to change in surface Plasmon as compare to their bulk metal parts. Semiconductor NPs are also reveals optical properties. Increases in the band gap energy due to the excitation of char carrier.

\section{ELECTRONIC PROPERTIES}

Conductance of the metal depends on mobility of the electrons and band structure. Motion of electrons in metal follows Ohm's law but when the size of this metal reduced to nanometre scale they does not necessarily follow Ohm's law[13]. Extremely small capacitance of the NPs shows coulomb blockade or coulomb staircase effect and enhanced electric properties. Metal NPs able to store charge by addition and removal of electrons and it is extremely sensitive to charges on neighbouring atoms. This charge storage capacity of metal NPs is supporting it for a good sensors application [14].

\section{a) Magnetic properties:}

Magnetic properties of NPs are related with two factors i.e. core acidity and super-paramagnetic and both of them change with particle size. Core activity of bulk material is low as it forms multiple domains; core activity reaches to its maximum in single domain of small particulate materials like NPs. In super paramagnetic, the ferro magnetic transition of a given sample is broadened due to the thermal fluctuation of the total moment on each particles of the sample, attributed to their single domain nature [31].

\section{b) Catalytic properties :}

Catalyst plays an important role in chemical and biological reactions, larger the surface area greater is the catalytic efficiency. So when the size approaches from bulk material to nano-level, surface area increases and consequently catalytic efficiency also increases. The unique surface structure facilitates high surface area and electronic structure useful for catalysis. Gold is noble metal at bulk level but when it comes to NPs range it shows good catalytic activity in oxidation of carbon monoxide[15-16].

\section{c) Biocompatibility:}

Due to the unusually properties of NPs, scientific community is trying to explore them for biomedical applications. But major concern with the NPs is there toxicity, bioavailability, uptake, sub-cellular distribution, short term and long term effects, metabolism and degradation etc. Some metal NPs shows lower toxicity, enhanced catalytic function, increased antimicrobial potential, and greater bioavailability than their bulk counter parts ${ }^{16}$. Gold N Psare extensively studied for their cytotoxic effect, it is untaken by mammalian cells through pinocytosis and distributed in lysosomal bodies[12]. Plants are tremendously available natural sources of bimolecular the plants consists of photochemical like proteins, bimolecular like amino acids, vitamins, proteins, enzymes, and polysaccharide honey, etc phenols, flavonoids, glycosides, alkaloids, Saponins, terpenes, etc. produced by plants are pharmacologically active till date about 200 phytoconstituents are used for biosynthesis of nanoparticles. The phytoconstients are hydrophobic in nature Their hydrophobicity unable to serve them as a stabilizing agent as well as capping agent $[13,14,15]$.

The previous reports shows that for the synthesis of Silver Nanoparticles two important factors are responsible 1) physiological condition 2) physical condition.

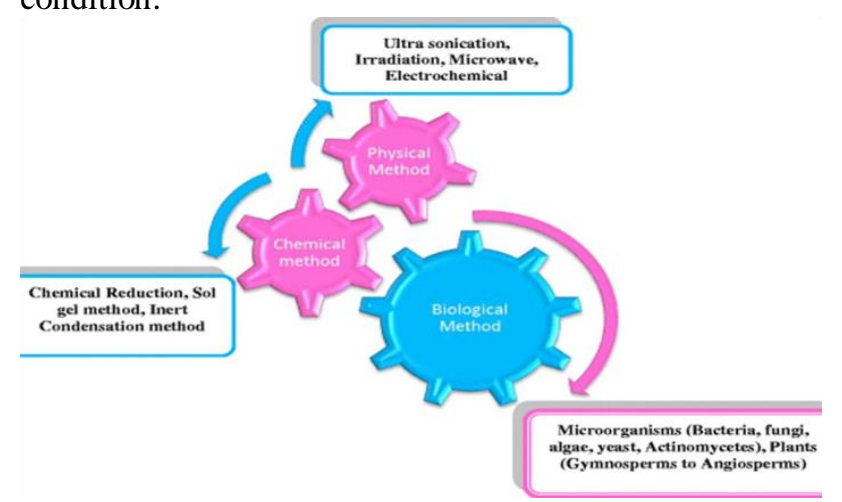

Fig. No.3 Methods of Nanoparticles synthesis

The physiological condition of plants depends upon geographical condition of plants habitat and the condition 


\section{International Journal of Engineering Applied Sciences and Technology, 2021 \\ Vol. 5, Issue 9, ISSN No. 2455-2143, Pages 189-194 \\ Published Online January 2021 in IJEAST (http://www.ijeast.com)}

of a plants at the time of reaction. The physical condition like concentration of silver nitrate, quantity of plant extract, ph of the plant extract, stirring condition of the reaction mixture etc. In this review article various aspects of Nanobiotechnology, the reaction of nanoparticle synthesis and applications of nanoparticle is highlighted.

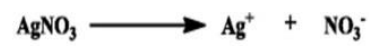

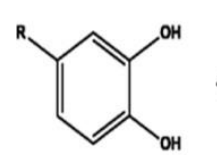

General molecular formula of plant polyphenols

Fig.4: Systematic representation of Silver Nanoparticles formations

During the process when we titrate silver nitrate solution with plant extract reaction of silver nano particles starts. The reaction starts immediately after the reactants mixes with each other The mechanism of formation of Silver nano particle involves activation, growth and stabilization termination. The activation process involves the reduction of metal ion and, nucleation of the reduced metal atom. The growth phase, referring to the spontaneous coalescence of a small adjacent Nanoparticle into a particle of a large size, accompanied by an increase in the thermodynamic stability of nanoparticle or the process referred to as Ostwald ripening. The termination phase in which the final shape of Nanoparticle is formed[18-19]. Consequentially, the fabricated nanoparticles stabilize by the bioactive compound of plant extract. The assorted factors such as reaction time, reaction solution $\mathrm{pH}$, temperature, and concentration of both plant extract and metal salt influence the morphology, size, and quality of fabricated nanoparticle [16].

Now a day's Nanobiotechnology and its application has entered in every field metallic and non metallic nanoparticles the nanoparticles must be different size, shape, and chemical composition . There are various method includes chemical reduction, gamma ray radiation, microwave assistant vapour deposition, thermal reduction. The previous reports shows that the size, shape, of the nanoparticles depends on the physical factors like, temperature of reaction solution, ph, concentration of silver nitrate and concentration of plants extract. The important other factor is stabilizing and reducing agent Formation of nanoparticles is a complex process .It involves the Adsorption kinetics of interplay in between the reducing agent and the metal ion. the exiting physical and chemical methods produces poisonous gases ,heat, radiation, noise, The stabilities and reducing agent, solvent used in these process have high risk of carcinogenicity[21]

Keeping all these disadvantages .The green synthesis is introduced in the last two decades. It is eco-friendly for the synthesis of nanoparticles. The Microorganism also serve as a good source of bimolecular for the synthesis of nanoparticles and are prepared by two ways.

\section{- Solvent mediums.}

- Various reducing agents

The Microorganism includes bacteria, algae, fungi, Actinomycetes, fungi yeast etc. Generally microorganism and different metals are interacting within the bacterial cells as part of bacterial physiology. Some microorganism has a property to accumulate heavy metals which is used to accumulate heavy metals which is used for biological and bioremediation. Microorganism serve as a factory for the synthesis of selenium, gold, silver, copper, some magnetic Nps from slayers of gypsum and calcium carbonate layers[ $22,23,24]$.

\begin{tabular}{|c|c|c|c|c|c|}
\hline \multicolumn{6}{|c|}{$\begin{array}{l}\text { Table No.1 : Various micro-organisms used for the biosynthesis of different size and shape } \\
\text { NPS }\end{array}$} \\
\hline Name of Microorganism & $\begin{array}{c}\text { Type of } \\
\text { NPs }\end{array}$ & \begin{tabular}{|l|l|} 
Size \\
$(\mathrm{nm})$
\end{tabular} & Shape & $\begin{array}{c}\text { Site of } \\
\text { Synthesis }\end{array}$ & References \\
\hline Trichoderma viridae & $\mathrm{Ag}$ & $5-40$ & Spherical & Extracellular & 35 \\
\hline Rhodococcus sp. & $\mathrm{Au}$ & $5-15$ & Spherical & Intracellular & 28 \\
\hline $\begin{array}{l}\text { Plectonemaboryanum } \\
\text { sp. }\end{array}$ & $\mathrm{Au}$ & $\begin{array}{c}<10- \\
25\end{array}$ & Cubic & Intracellular & 29 \\
\hline $\begin{array}{l}\text { Plectonema boryanum } \\
\text { UTEX } 485\end{array}$ & $\mathrm{Au}$ & $\begin{array}{c}10 \\
\mathrm{~nm}-6 \\
\mu \mathrm{m}\end{array}$ & Octahedral & Extracellular & 29 \\
\hline Escherichia coli & $\mathrm{Au}$ & $20-30$ & $\begin{array}{l}\text { Triangles, } \\
\text { Hexagons }\end{array}$ & Extracellular & 30 \\
\hline Escherichia coli & $\mathrm{Au}$ & $20-30$ & $\begin{array}{l}\text { Triangles, } \\
\text { Hexagons }\end{array}$ & Extracellular & 30 \\
\hline Escherichia coli & $\mathrm{Au}$ & $15-30$ & Not available & Extracellular & 31 \\
\hline Escherichia coli & $\mathrm{Au}, \mathrm{Ag}$ & $10-50$ & Spherical & Intracellular & 34 \\
\hline Escherichia coli & $\mathrm{Ag}$ & $5-40$ & Spherical & Extracellular & 35 \\
\hline Escherichia coli & $\mathrm{Ag}$ & $\begin{array}{l}50- \\
200\end{array}$ & Pyramidal & Extracellular & 36 \\
\hline Escherichia coli & $\mathrm{Ag}$ & $5-25$ & Spherical & Extracellular & 39 \\
\hline Escherichia coli & $\mathrm{Ag}$ & $25 \pm 8$ & Spherical & Extracellular & 40 \\
\hline Escherichia coli & $\mathrm{Ag}$ & $5-50$ & Spherical & Extracellular & 40 \\
\hline Escherichia coli & $\begin{array}{c}\mathrm{Au} \\
\mathrm{Au} / \mathrm{Ag}\end{array}$ & $\begin{array}{c}32, \\
20-50\end{array}$ & Spherical & $\begin{array}{l}\text { Intracellular, } \\
\text { extracellular }\end{array}$ & 41 \\
\hline Escherichia coli & $\mathrm{Pt}$ & 5 & Not available & Intracellular & 42 \\
\hline Escherichia coli & $\mathrm{Hg}$ & $2-5$ & Spherical & Intracellular & 43 \\
\hline Escherichia coli & $\mathrm{CdTe}$ & \begin{tabular}{l|l|}
$2.0-$ \\
3.2 \\
\end{tabular} & Spherical & Extracellular & 44 \\
\hline Escherichia coli & $\mathrm{Au} / \mathrm{Ag}$ & $9-25$ & $\begin{array}{l}\text { Irregular } \\
\text { polygonal }\end{array}$ & Extracellular & 45 \\
\hline Escherichia coli & $\mathrm{Pd}$ & 50 & Spherical & Extracellular & 46 \\
\hline Escherichia coli & $\mathrm{Fe}_{3} \mathrm{O}_{4}$ & $40-50$ & $\begin{array}{c}\text { Rectangular, } \\
\text { rhombic, hexagonal }\end{array}$ & Extracellular & 47 \\
\hline Escherichia coli & $\mathrm{Sb}_{2} \mathrm{O}_{3}$ & $2-10$ & Spherical & Intracellular & 48 \\
\hline Escherichia coli & $\mathrm{BaTiO}_{3}$ & $20-80$ & Tetragonal & Extracellular & 49 \\
\hline Escherichia coli & $\mathrm{TiO}_{2}$ & $6-13$ & Spherical & Extracellular & 50 \\
\hline Escherichia coli & $\mathrm{BaTiO}_{3}$ & $4-5$ & Spherical & Extracellular & 51 \\
\hline Escherichia coli & $\mathrm{ZrO}_{2}$ & $3-11$ & Spherical & Extracellular & 52 \\
\hline Escherichia coli & $\mathrm{CdS}$ & 8 & Cubic & Intracellular & 53 \\
\hline
\end{tabular}

There are reports many scientists have worked on different microorganism to get the nanoparticles . the table illustrate the information.

The Actinomycetes have both the characteristics of fungi as well as bacteria. Actinomycetes produce the secondary metabolites such as antibiotics. The alkali hemophilic Actinomycetes of thermospora monosporaspecies, Synthesis gold ions Nps, under alkaline condition[25]. Yeast also have ability to synthesize gold Nps and are also synthesized by intracellular by using the fungi U.lute album .theirs is a report gold nanoparticles of 2-20nm size have synthesized from Alfa Alfa plants. It is also reported that copper ,silver, gold, nickel oxide, zinc oxide nanoparticles from Artemisia pollens. Brasilika Juncea Medica sativa and Helianthus annus. Some plants have ability to accumulate heavy metal they are called as hyperaccumulators. These accumulated metal can be used as metal nanoparticles. The plants like xerophytes, Mesophytes and hydrophytes can synthesize nanoparticle in range 2-5 $\mathrm{nm}[17]$.

The physical and chemical methods of biosynthesis of nanoparticles should be cost- effective. by keeping this in view Scientist have developed the 
methods which use the microorganism and plant extracts for synthesis. ${ }^{[12]}$. Nanoparticles are prepared in two ways 1) by the solvent medium. 2) by the different reducing agents. The photochemical present in plants can cap to one another due to their hydrophobicity. Most of the nanoparticles synthesized by various microorganisms and plants are less toxic, easily available capping, and reducing agents.

Synthesis of nanoparticles using bacteria is a new physiological approach. Synthesized nano-sized material from the bacterial cells has a new method for the synthesis of NPs. Microorganisms and different metals are interacting within the bacterial cell as a part of bacterial physiology. The ability of microorganisms or accumulation of metals is a profitable biotechnological technique used for bioleaching and bioremediation. Most bacteria can produce the inorganic materials by intracellular and extracellular, microorganisms act as one type of factory to synthesize the NPS like selenium, gold, silver, copper, cadmium, etc. Microorganisms to make the Magnetic NPs and Slayers form gypsum and calcium carbonate layers[17].Synthesis of nanoparticles using Actinomycetes. Actinomycetes are the type of microorganisms that have a significant character of fungi.

The plants investigated, Brasslike juncea has better metal accumulating ability and later assimilating it as nanoparticles [18]. Important phytoconstituents are accountable have been recognized as terpenoids, flavones, and carboxylic acids they are shown under the light of IR, NMR, HPTLC technique spectroscopic studies. Nanoparticles are also synthesized with xerophytes, mesophytes, and hydrophytes are in the range of 2-5nm [18]. Various synthesis of NPs and their sources presented in the table.

The studies conducted form last few years shows that the biological agents such as microorganism like bacteria Actinomycetes .algae, fungus, yeast the bimolecular like amino acids, vitamins, proteins, enzymes, and polysaccharide honey etc [19]. The biochemical processing capabilities vary with the biological entity that may be impressively used to fabricate particular metallic or metal oxide Nanoparticles. The synthesis of nanoparticle from microbes is a hectic process considering microbes, optimization of culturing parameters such as $\mathrm{pH}$, light, nutrients, mixing speed, temperature and buffer strength can significantly increase enzyme activity that eventually helps in the formation of nanoparticle [20] Plant Synthesis of various nanoparticles the first of all biosynthesis of nanoparticle done by Gardea-Toresday et al (1999) after the 1999 various research worked on the number of plants.[21]

Their are report various scientist worked on different plants tabulated in table 2

\begin{tabular}{|c|c|c|c|c|}
\hline $\begin{array}{c}\text { Name of } \\
\text { plant }\end{array}$ & $\begin{array}{c}\text { Type of } \\
\text { Niño } \\
\text { particle }\end{array}$ & $\begin{array}{l}\text { Biophysic al } \\
\text { Technique }\end{array}$ & $\begin{array}{l}\text { Micro Biological } \\
\text { Activity }\end{array}$ & Result \\
\hline $\begin{array}{l}\text { Camellia } \\
\text { Sine sis }\end{array}$ & $\begin{array}{l}\text { Silver, } \\
\text { Gold }\end{array}$ & $\begin{array}{l}\text { U.V.V Vis, NIR, } \\
\text { TEM }\end{array}$ & & $\begin{array}{c}448 \mathrm{~nm}-\mathrm{Au}, 470 \mathrm{~nm}-\mathrm{Ag}, \text { Size } \\
\text { of Particle } 40 \mathrm{~nm}\end{array}$ \\
\hline & & $\begin{array}{c}\text { FTIR, } \\
\text { U.V. Vis, XRD, }\end{array}$ & $\begin{array}{c}\text { E.coli \& Staphy loccus } \\
\text { Aureus. }\end{array}$ & $\begin{array}{c}450 \_450 \mathrm{mn} \\
\text { U.V.Peak, FTIR-2798.4, }\end{array}$ \\
\hline
\end{tabular}

\begin{tabular}{|c|c|c|c|c|}
\hline Banana Peel & Silver & \begin{tabular}{|c|} 
SEM, TEM, \\
Thermal Studies.
\end{tabular} & & $2428.5,1595,1384,1108$. \\
\hline \begin{tabular}{|l|} 
Mimusoa ps \\
elengi. Linn
\end{tabular} & Silver & \begin{tabular}{|l} 
U.V. Vis, SEM, \\
FTIR, XRD \\
\end{tabular} & $\begin{array}{c}\text { Multidrug Resistant } \\
\text { Bacteria }\end{array}$ & U.V. $420 \mathrm{~nm}$ \\
\hline $\begin{array}{c}\text { Pongami a } \\
\text { Pinnata }(L) \\
\text { Pierre }\end{array}$ & Silver & XRD TEM U.V. & \begin{tabular}{|c|} 
Escherichi Coli $($ ATCC \\
8739) \\
Staphylococu s aureus \\
ATCC 6538P \\
pseudomonas Aeruginosa \\
(ATCC 9027) \\
Klebsilla Pneumonia. \\
\end{tabular} & $\begin{array}{l}\text { Size-2030nm FTIR- } 1069, \\
1240,1314,1390,1447, \\
1515,15611620,1653, \\
3656 \mathrm{Cm}\end{array}$ \\
\hline $\begin{array}{l}\text { Morinda } \\
\text { citrifolia }\end{array}$ & Silver & U.V.Vis FTIR & E.Coli \& Staphy loccus & Size $3-10 \mathrm{~nm}$ \\
\hline
\end{tabular}

\begin{tabular}{|c|c|c|c|c|}
\hline$L$ (noni) & & SEM EDS TEM & Aureus. & \\
\hline $\begin{array}{l}\text { Morindac } \\
\text { itrifolia (noni) } \\
\text { root extract }\end{array}$ & Silver & $\begin{array}{l}\text { U.V., FTIR, } \\
\text { FESEM }\end{array}$ & $\begin{array}{c}\text { Cytotoxicity of Hela } \\
\text { Cell }\end{array}$ & $\begin{array}{l}\text { U.V. Peak } 413 \mathrm{~nm} \\
\text { Size- } 30-35 \mathrm{~nm}\end{array}$ \\
\hline \multirow[t]{2}{*}{$\begin{array}{l}\text { Morinda } \\
\text { citrifolia L } \\
\quad \text { (noni) }\end{array}$} & Silver & $\begin{array}{l}\text { FTIR, U.V. } \\
\text { HRTEM, SEM }\end{array}$ & \begin{tabular}{|c|} 
Escherichi coli \\
Pseudomonas \\
aeroginosa Klebsiella \\
Pneumoniae \\
Entercobacter \\
aerogene Bacillus \\
Ceres \\
Enterococci.sps \\
\end{tabular} & $\begin{array}{l}\text { U.V. Peak } 420 \text { Size - } \\
\text { 10- } 60 \mathrm{~nm}\end{array}$ \\
\hline & Silver & & \begin{tabular}{|c|} 
Human Lung \\
fibroblast cell IMR-90 \\
Human Glioblastoma \\
Cell U251 Micro \\
nuclieus assay
\end{tabular} & $40 \mathrm{~nm}$ \\
\hline \multirow[t]{2}{*}{$\begin{array}{c}\text { Brucea Javanica } \\
\text { (L) Merr }\end{array}$} & Silver & TEM. U.V. & & 38-14nm Size \\
\hline & Silver & $\begin{array}{l}\text { U.V., SEM., } \\
\text { TEM., } \\
\text { DLS., EDS.,FTI } \\
\text { R }\end{array}$ & $\begin{array}{l}\text { Escherichia coli } \\
\text { Bacillus substilils }\end{array}$ & \begin{tabular}{|c} 
200nm Reddish \\
brown, FTIR 1025, \\
1074, \\
$2263, \quad 1320$, \\
$1610,1381$.
\end{tabular} \\
\hline Azardica Indica & Silver & $\begin{array}{c}\text { U.V.,FTI } \\
\text { R., DLS., TEM. }\end{array}$ & \begin{tabular}{|c|} 
Escherichia coli \\
Staphyloccus Aureus
\end{tabular} & U.V. 436-446 \\
\hline Jeranium Leaf & Silver & $\begin{array}{c}\text { U.V., FTIR, } \\
\text { Zeta potantion } \\
\text { TEM. }\end{array}$ & & $\begin{array}{c}\text { U.V. 420nm Size - } 25- \\
150 \mathrm{~nm} .\end{array}$ \\
\hline
\end{tabular}

\begin{tabular}{|c|c|c|c|c|}
\hline $\begin{array}{l}\text { Origanu } m \\
\text { Vulaare L }\end{array}$ & Silver & $\begin{array}{l}\text { U.V. peak 430nm, } \\
\text { FTIR. } 3268 \mathrm{~cm}-1, \\
2930 \mathrm{~cm}-1, \\
1610 \mathrm{~cm}-1, \\
3389 \mathrm{~cm}-1, \\
2923 \mathrm{~cm}-1\end{array}$ & \begin{tabular}{|} 
Pseudomonas Aeruginosa ATCC \\
27584 \\
Salmanoella Typhimurum ATCC \\
14028, ATCC-25922 \\
Staphyloccus Aureus ATCC-29213 \\
Staphloccus Epidermis MTCC \\
3615, \\
Shigella Sonnel ATCC 11060 \\
Staphylococc us Aureus ATCC \\
29213 , \\
Staphalococc us Epidermis \\
MTCC-3515, \\
Fungus Microccus Luteus (ATCC- \\
$4696)$ \\
Aspergillus Flavus ATCC 9643 \\
Alternaria Alternata ATCC 13963 \\
Phialo Phalophora Alba ATCC \\
9625 . \\
\end{tabular} & $\begin{array}{l}\text { U.V. Peak } 430 \mathrm{~nm} \\
\text { Size- } 12-15 \mathrm{~nm} \text {. }\end{array}$ \\
\hline $\begin{array}{c}\text { Jalinum } \\
\text { triangula re } \\
\text { (Jac) Wild } \\
\text { Sliver }\end{array}$ & Silver & U.V., FTIR. & E.Coli Candida Albicans & \\
\hline $\begin{array}{l}\text { Solanum } \\
\text { Indicum } L\end{array}$ & Silver & $\begin{array}{c}\text { TEM.,FTI R., } \\
\text { SEM., EDS., } \\
\text { FTIR- } 1765, \\
1667, \\
1165-730- \\
\text { cm } \\
\end{array}$ & rat Splenocytes, MTT assay & $\begin{array}{l}\text { Yellowish Brown } \\
\text { Size- 10-50nm. }\end{array}$ \\
\hline
\end{tabular}

\begin{tabular}{|c|c|c|c|c|}
\hline Partheni um leaf & Silver & U.V., TEM. & & 474nm, Size $50 \mathrm{~nm}$. \\
\hline $\begin{array}{c}\text { Euphorbi a } \\
\text { Antiquor um } L . \\
\text { Latex extract. }\end{array}$ & Silver & $\begin{array}{l}\text { U.V., TEM., } \\
\text { XRD., EDAX. }\end{array}$ & \begin{tabular}{|c|} 
Anticancerou s Activit \\
- MTT Assay \\
Helar \\
line, Larvicidal Activit
\end{tabular} & \begin{tabular}{|c|} 
U.V. Peak 438., FTIR \\
Spctra -652.69, 697.71 \\
$762.31,829.46$, \\
$1124.94,1402.35$ \\
$1570.75,3431.78$
\end{tabular} \\
\hline \multirow[t]{2}{*}{ Areca Nut } & Silver & $\begin{array}{l}\text { U.V. } \\
\text { Visible, XRD., } \\
\text { FESEM., TEM., } \\
\text { EDX. }\end{array}$ & & \begin{tabular}{|c|} 
Size- $52 \mathrm{~nm}$, FTIR- \\
$1438.85 \mathrm{~cm}-$ \\
$1,1608.58$ \\
$\mathrm{~cm}-1,1700.10$ \\
$\mathrm{~cm}-1$, Thermal Stability \\
TGA. \\
\end{tabular} \\
\hline & Silver & $\begin{array}{l}\text { U.V. Vis., Particl } \\
\text { Size Analyzer } \\
\text { SEM., TEM., EDS } \\
\text { FTIR. }\end{array}$ & $\begin{array}{l}\text { Escherichia Coli } \\
\text { Bacillus Speces. }\end{array}$ & \begin{tabular}{|} 
FTIR-1025, 1074, 1320 \\
1381, 1610, 2263cm- \\
$\mathrm{cm}$, Yellowish to Red \\
brown 425-475nm peak
\end{tabular} \\
\hline $\begin{array}{l}\text { Psidium } \\
\text { Guajava }\end{array}$ & Silver & U.V., TEM. & $\begin{array}{c}P . \\
\text { Aeruginosa }\end{array}$ & $\begin{array}{c}\text { U.V. Peak } 435 \mathrm{~nm} \text { Size } \\
40 \mathrm{~nm} .\end{array}$ \\
\hline
\end{tabular}




\section{International Journal of Engineering Applied Sciences and Technology, 2021 Vol. 5, Issue 9, ISSN No. 2455-2143, Pages 189-194 \\ Published Online January 2021 in IJEAST (http://www.ijeast.com)}

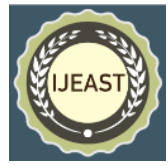

A new approach to prevent to combat microbial pathogen is by use of nanoparticles especially synthesized with the help of natural medicinal plants. Medicinal plants are already well known for many therapeutic values and have been used for ages for curing many diseases and disorders including infectious diseases this is because of the phytoconstituents present in them. The phytoconstituents or secondary metabolites present in the plant. The secondary metabolites or phytoconstituents can be used for drugs[21]

\section{A. Applications of silver nanoparticles.-}

Silver nanoparticle has tremendous applications in medicine, food industry, cosmetic paints, catalyst, biomedical, textile, and environment, and the textile industry.

A silver nanoparticle is used in catheters and cardiovascular and bone implants. As Silver Nanoparticles have good antibacterial, antifungal, anti-inflammatory, antiantigenic, and ant-permeability activities. So Silver Nanoparticles are used as an antimicrobial agent in surgically implanted cathedrae, bone, and teeth implants to reduce the infection caused during surgery. Silver Nanoparticles destroy the biofilm formed by pathogenic invasion. [22]

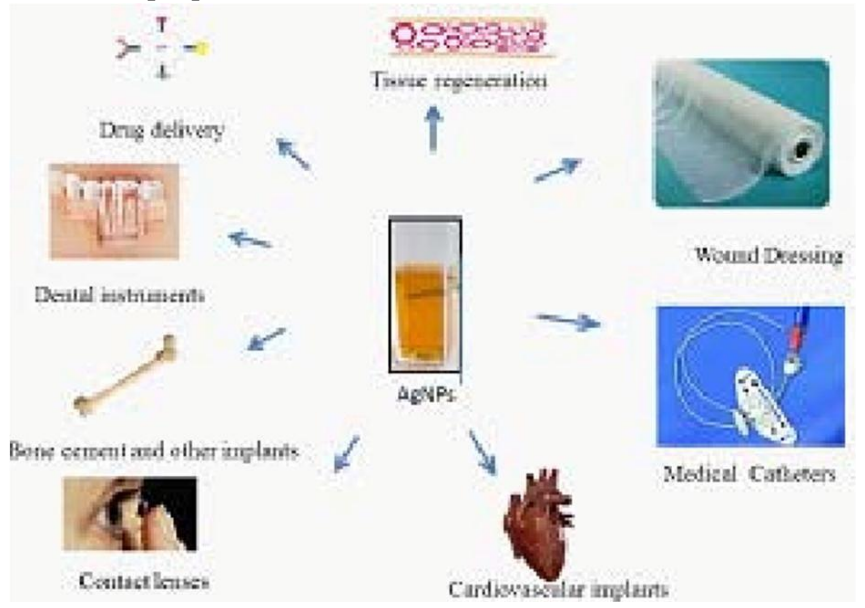

Figure 6: Applications of Silver nanoparticles

Polyethylene is used in an insert for artificial joint replacement, but its application is somehow limited due to wear and tear. This drawback of the polymer can be significantly overcome by the addition of silver nanoparticle.

The silver nanoparticle is also integrated with Polymethyl methacrylate which is used as a block of bone cement in synthetic joint replacement Silver Nanoparticles are also used in the nanocrystalline dressing for wound healing as surgical mashes are of high-risk pathogenic invasion to enhance the effectiveness of mashes Silver Nanoparticles are integrated with dressing mashes. Silver Nanoparticles are added with poly-(-3-hydroxy valerate) nanofiber which is used as a bone and tissue regenerating agent, Silver Nanoparticles are also used in bio imaging and targeting the damaged cells. AgNps are also be used in food preservation and paints, pharmaceuticals, products and nanoparticles have been used to treat burns, wounds, and infections. Besides, various salts of silver and their derivatives have been used as antimicrobial agents. Numerous studies have reported that $\mathrm{Ag}$ nanoparticles exhibit antimicrobial properties. Ag nanoparticles have been studied as a medium for antibiotic delivery, synthesis of composites for the use as disinfecting filters, and coating materials. [85-88] Owing to their small sizes and higher surface-to-volume ratio, Ag nanoparticles possess a wider contact area with microorganisms. This property can enhance the biological and chemical activity, hence provides $\mathrm{Ag}$ nanoparticles with high antibacterial activity. Ag nanoparticles can disturb the functions of cell membranes such as permeability and respiration. Furthermore, upon penetration of the bacteria cell, Ag nanoparticles can disturb and react with the functions of sulfur-containing proteins and phosphorus-containing compounds such as deoxyribonucleic acid (DNA). which leads to cell death. [23]

\section{CONCLUSION}

Nanobiotechnology is one of the emerging branches of Nanotechnology. Silver Nanoparticles are synthesized by various biomolecules present in nature. microorganism and plants are the major sources of secondary metabolites' which are used for the synthesis of Silver Nanoparticles. Maintenance of bacterial culture is the major problem for the synthesis of Silver Nanoparticles from microorganism like bacteria, fungi, Actinomycetes .plant are the excellent source of capping and stabilizing agent for the synthesis of Silver Nanoparticles. There are about 2000 biological sources from which Nanoparticles have been synthesized silver metal itself is a good antibacterial agent from ancient times. Silver Nanoparticles in medical sciences. It is used in drug delivery, in cancer treatment; it is also used in wound dressing, tissue regeneration, contact lenses. Silver Nanoparticles also act as bone and teeth implants as bone cement.

\section{REFERANCES}

1) Ball, Philip. " Made to measure: New materials for the 21st century",Princeton University Press, 1999.

2) Shaw, C. Frank. "Gold-based therapeutic agents" ,Chemical reviews ,99.9, 2589-2600.1999.

3) Skomski, Ralph. "Nanomagnetics, Journal of physics:Condensed matter, "15.20 R841.2003.

4) Chen, P., Song, L.Y. and Liu, Y.K.. "Synthesis of Silver Nanoparticles by Gamma-Ray Irradiation in Acetic Water Solution Containing Chitosan",Radiation Physic,1165 -1168. 2007. http://dx.doi.org/ 10.1016/j.radphyschem.2006.11.012

5) Zhang, W.Z., Qiao, X.L. and Chen, J.G. "'Synthesis and Characterization of Silver Nanoparticles in AOT MicroEmulsion System". Chemical Physics, 300, 495-500. 2006.http://dx.doi.org/10.1016/j.chemphys.2006.09.029

6) Yang, J. and Pan, J. (2012) . "Hydrothermal Synthesis of Silver Nanoparticles by Sodium Alginate and Their Applications in Surface-Enhanced Raman Scattering and Catalysis."Acta Materialia, 60, 47534758.http://dx.doi.org/10.1016/j.actamat.2012.05. 


\section{International Journal of Engineering Applied Sciences and Technology, 2021 \\ Vol. 5, Issue 9, ISSN No. 2455-2143, Pages 189-194 \\ Published Online January 2021 in IJEAST (http://www.ijeast.com)}

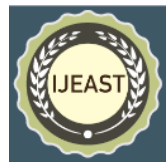

7) Shukla, R. . "Biocompatibility of gold nanoparticles and their endocytotic fate inside the cellular compartment: a microscopic overview." Langmuir ,21.23, 10644-10654.2005.

8) Abécassis, Benjamin, et al. . "Probing in situ the nucleation and growth of gold nanoparticles by smallangle X-ray scattering." Nano letters ,7.6, 17231727.2007.

9) Abid, J.P., Wark, A.W., Brevetm, P.F., and Girault, H.H. (2002) . "Preparation of SilverNanoparticles in Solution from a Silver Salt by Laser Irradiation."Chemical Communications, 7, 792-793. http://dx.doi.org/10.1039/b200272h

10) Fayaz, A.M., Balaji, K., Kalaichelvan, P.T., and Venkatesan, R. (2009) . “ Fungal Based Synthesis of SilverNanoparticles-An Effect of Temperature on the Size of Particles." Colloids and Surfaces B: Biointerfaces, 74, 123-126. http://dx.doi.org/ 10.1016/j.colsurfb.2009.07.002

11) Perni, S., Hakala, V. and Prokopovich, K. (2014) . "Biogenic Synthesis of Antimicrobial Silver Nanoparticles Caped with L-Cystine". Colloids and Surfaces A: Physicochemical and Engineering Aspects, 460, 219-224.

12) Shukla, R. "Biocompatibility of gold nanoparticles and their endocytotic fate inside the cellular compartment: a microscopic overview. "Langmuir ,21.23 , 1064410654.2005

13) Abécassis, Benjamin, e. "Probing in situ the nucleation and growth of gold nanoparticles by small-angle X-ray scattering." Nano letters ,7.6, 1723-1727.2007.

14) Hasim, H., Rao, P. V., Sekar, A. C., Muthuraju, S., Asari, M. A., \& Sirajudeen, K. N. S. (2020). “ Green synthesis and characterization of silver nanoparticles using Tualang honey and evaluation of their antioxidant activities", Advances in Natural Sciences.

15) Arya, V. "Living Systems: eco-friendly nanofactories," Digest Journal of Nanomaterials \& Biostructures (DJNB), 5.1 .2010.1Prakash, P., Gnanaprakasam, P., Emmanuel, R., Arokiyaraj, S., \& Saravanan, M. (2013). . "Green synthesis of silver nanoparticles from leaf extract of Mimusops elengi, Linn. for enhanced antibacterial activity against multi drug resistant clinical isolates".,Colloids and Surfaces B: Biointerfaces, 108, 255-259.

16) AshaRani, P. V., Low Kah Mun, G., Hande, M. P., \& Valiyaveettil, S.. "Cytotoxicity and genotoxicity of SilverNanoparticles in human cells". ACS Nano, 3(2), 279-290.

17) Sengottaiyan, A., Mythili, R., Sivakumar, T., Aravinthan, A., Kamala-Kannan, S., Manohara Kim, J. H. (2016). "Green synthesis of Silver Nanoparticles using Solanum Indicum L. and their antibacterial, splenocyte cytotoxic potentials". Research on Chemical Intermediates, 42(4), 3095-3103.

18) Ge, M., Cao, C., Huang, J., Li, S., Chen, Z., Zhang, K. Q., Lai, Y. (2016). "A review of one-dimensional TiO 2 nanostructured materials for environmental and energy applications", Journal of Materials Chemistry, 4(18), 6772-6801.

19) Nanda, A. and Saravanan, M. (2009) . “ Biosynthesis of Silver Nanoparticles from Staphylococcus aureus and Its Antimicrobial Activity against MRSA and MRSE", Nanomedicine: Nanotechnology, Biology and Medicine, 5, 452-456. http://dx.doi.org/ 10.1016/j.nano.2009.01.012

20) Cheng, K.M., Hung, Y.W., Chen, C.C., Lin, C.C., and Yong, J.J. (2014) . "Green Synthesis of Chondroitin Sulfate- Capped Silver Nanoparticles: Characterization and Surface Modification. Carbohydrate Polymers", 110,195202.http://dx.doi.org/10.1016/j.carbpol.2014.03. 053

21) Chen, Q., Jiang, H., Ye, H., Li, J. and Huang, J. (2014). "Preparation, Antibacterial, and Antioxidant Activities of Sil-ver/Chitosan Composites". Journal of Carbohydrate 